\title{
The Subversion of the Oriental Stereotype in M. Butterfly
}

\author{
Songfeng Wen ${ }^{1}$ \\ ${ }^{1}$ Department of Foreign Languages, Zhengzhou University of Light Industry, Zhengzhou, China \\ Correspondence: Songfeng Wen, Department of Foreign Languages, Zhengzhou University of Light Industry, \\ Zhengzhou, 450000, China. E-mail: jonathanwen@163.com
}

$\begin{aligned} & \text { Received: February 16, } 2013 \quad \text { Accepted: March 13, } 2013 \quad \text { Online Published: April 26, } 2013 \\ & \text { doi:10.5539/ells.v3n2p44 URL: http://dx.doi.org/10.5539/ells.v3n2p44 }\end{aligned}$

\begin{abstract}
This paper is to examine the Oriental stereotype propagated by Giacomo Puccini's Madame Butterfly and how it is subverted in David Henry Hwang's M. Butterfly. Puccini portrays a docile, self-sacrificial Oriental woman who is totally submissive to and finally dies for her unworthy White lover. The opera's popularity has perpetuated the stereotype of an ideal Oriental woman. In Hwang's M. Butterfly, the stereotype of the ideal Oriental woman is subverted as the gender roles and the power structure of the Oriental woman and the Occidental man have been reversed. The White man, Gallimard, rather than a powerful sexual predator, is manipulated by his Oriental lover, a man masquerading woman, and finally dies for his Oriental lover. By analyzing the stereotype in Madame Butterfly and its subversion in M. Butterfly, it is hoped to reveal the insidiousness of stereotyping in understanding different cultures and peoples and it is also called for to rid people of stereotyping in cross-cultural communications.
\end{abstract}

Keywords: Madame Butterfly, the Oriental stereotype, M. Butterfly, subversion, reversals

\section{Introduction}

In his book, Orientalism, Edward Said concludes that many Western writings about the East are not depicting, but rather, restructuring and intending to establish their authority over the Orient in a racist, sexist, and imperialist manner. "The Orient was almost a European invention, and had been since antiquity a place of romance, exotic beings, haunting memories and landscapes, remarkable experiences....[and] has helped define Europe as its contrasting image, idea, personality, experience" (Said, 1978, 1). The same is true with Asians and Asian culture in their representations in the West. Westerners tend to generalize their occasional observations about Asian culture and personality and frequently reduce them to a set of easily recognizable characteristics to reaffirm white supremacy and thus stereotyped. "The Orient was Orientalized, not only because it was discovered to be 'Oriental'... but because it [was] made Oriental" (Said, 1978, 5-6).

The Orient was made the Other by the Occident due to its differences from the Occident. The Orient, "invented" by Europe, has always been represented not by themselves, but by the Occident as a contrast to Europe. The relationship between the West and the East is frequently polarized as the antithesis of the savage and the civilized, the pervert and the rational, the passive and the aggressive, the feminine and the masculine. With absolute advantages in economic power and military might, Westerners have taken for granted that the Occident is superior to the Orient. This unconscious imperialistic mentality and the sense of racial supremacy make the Western men believe in their status as the privileged class. Considering themselves belonging to a superior and masculine culture, Western men believe that Oriental people want to be dominated and that the Orientals tend to model themselves according to Occidental standards. Being in an inferior position, the Orient has to be cultured by the Occident. It is the "White man's burden" in the words of Kipling, the British colonial bard, to take the responsibility to civilize the Oriental race and culture. This Oriental mentality helps to justify the colonization and subjugation of the East by the West and makes it a self-evident fact that the Orient needs to submit itself to the Occident. Therefore, the relationship between the West and the East has been "one of power and domination and of a complex cultural hegemony" (Said, 1978, 5) in Western writings about the East.

Apart from the racialist dimension, Orientalism also has its inherently sexist element. The West usually considers its conquest of the East similar to the domination of the man over the woman. To show the masculine power of the Orient, the Occident frequently uses the strategy of feminizing the East in its representations in the West. Eastern cultures and peoples are frequently seen as uncivilized. Eastern men are generally feminized and thus 
easily vanquished by the Westerners. By feminizing the Oriental man and depreciating the Oriental culture, the West feels its superiority to the East. By conquering the East, the Western masculinity is asserted. Eastern women, as both the "weaker", feminine sex, and members of the East, naturally fall victim to the Orientalist stereotyping. They are frequently the fantasized ideal Asian woman who, submissive and vulnerable, and hence can be easily dominated by the masculine power of the Western man. The stereotyped Western domination of the Eastern woman fits into the Western men and makes them feel more assured of their manhood if they are able to sexually dominate the Oriental woman.

Giacomo Puccini's Madame Butterfly has been widely acclaimed in the West and thus popularized the fantasy of the Oriental woman as the submissive, self-sacrificial lover for the White man. However, Madame Butterfly is by nature stereotyping the Orient and the Orientals rather than depicting the reality. As the Orient is "invented" by the West, this Oriental stereotype is created by the Occident simply to reinforce the White man's sexual and racial superiority. Yet, David Henry Hwang, the Chinese American playwright, tells a seemingly similar, yet highly different story in his Tony Award-winning play, M. Butterfly. The playwright intentionally structures his play in contrast to Madame Butterfly with the purpose of subverting the Orientalist thinking mode. The gender roles between the Oriental woman and the Occidental man and the power structure between the man and the woman are reversed.

\section{Puccini's Madame Butterfly: The Propagation of the Butterfly Stereotype}

Stereotyping Eastern women is the Western men's way to create the fantasy of their male power. Among all kinds of stereotypes of Eastern women, the most popular one is the ideal Asian woman, the heroine in the world renowned opera, Madame Butterfly, created by Giacomo Puccini in 1904. Cio-Cio-San, a submissive Japanese geisha, is sold to an American Navy Captain named Pinkerton in a fake wedding contract. Cio-Cio-San is so submissive to Pinkerton that she makes Pinkerton her whole world. Her love for Pinkerton is unconditional and purely sacrificial. She gives up her Buddhist belief to convert to her white lover's religion. For this she loses her family and friends, who renounce her for her betrayal of their religious faith. Soon after the marriage, Pinkerton departs for America. During Pinkerton's absence, Cio-Cio-San delivers a baby boy and waits for his return in spite of the courtship of a rich Japanese man. But her love for Pinkerton can never be returned as Pinkerton, the White man, takes it for granted. When Pinkerton does return three years later with his American wife to claim his son, Cio-Cio-San gives him the baby and commits suicide for the unworthy White man in despair.

The opera is the perfect embodiment of cultural stereotyping. Pinkerton, the white man, does not cherish an Oriental and WOMAN as a human being. His first judgment of Cio-Cio-San is not made based on Cio-Cio-San, the real person, but on stereotypes about Japan, as is shown by his remarks in his first meeting with Cio-Cio-San, "Heavens! Why, I know her already! Long before ever setting foot in Japan, I had met with her on every fan, on every teacup" (Loti, 1985, 69). It can be seen that Pinkerton has been brainwashed by the stereotype of an ideal Eastern woman, who is "shy lotus blossom of China doll: demure, diminutive and deferential...tittering behind her man, and best of all, devoted body and soul to serving him (Ling, 1990, 99). Moreover, as is often the case with Orientalist portrayals of the East, Cio-Cio-San is stereotyped with the familiar Orientalist model. Her Japanese identity is simply marked by various traditional Japanese symbols that are romantic or exotic to Western eyes. For example, Cio-Cio-San is a geisha, which is considered to be a paragon of Japanese women in Western mentality; she commits suicide in a manner that is frequently associated with Japan. So her submission to Pinkerton indicates both the submission of the Orient to the Occident, and the submission of female to male.

It is traditionally believed that men are superior to women. It is especially true when it comes to Eastern women and Western men. Pinkerton, who sees Cio-Cio-San as a little play thing, does not treat Cio-Cio-San on an equal footing. When Cio-Cio-San is renounced by her family for her marriage with a "foreign devil", Pinkerton orders all to depart, "Leave the place on the instant, here I am master..." (Carignani, 1906, 29). Cho-Cho-San is stereotyped as extremely submissive, trying her best to please her White lover. When Pinkerton shows disapproval of her dowry, Cio-Cio-San says, "You mind it? [Throws away the pot of paint] There!" (Carignani, $1906,22)$ She is so docile that she even agrees to give Pinkerton her son, saying "[solemnly] his son I will give him if he will come to fetch him" (Carignani, 1906, 69) when the American wife comes to claim the son.

Cio-Cio-San, the Butterfly, who is "beautiful, exotic, loving, yielding and not binding, giving all and demanding nothing" (Kerr, 1991, 125), enjoys great popularity in the West because such a woman fulfills the Occidentals' expectations of an Oriental woman. As Kerr further pointed out, "it was not only Puccini who enjoyed the spectacle of Butterfly's suffering. It filled the Opera house; it was something people wanted" (Kerr, 1991, 124). In the Westerners' eyes, the beauty and the tragedy of the opera lies in the fact that the Asian woman sacrifices everything she has and ultimately dies for her cruel White lover. In Puccini's portrayal, "men are men, women 
are women, Japanese Japanese, Americans Americans, as defined by familiar narrative conventions. And the predictable happens: West wins over East, Man over Woman, White man over Asian Woman" (Kondo, 1990, 10) This kind of plot fits the traditional vision of Oriental women loving Occidental men unconditionally. So Butterfly has become "a discourse about the Orient... a structure of thinking...in literary and artistic production, in political and scientific writings" (Loomba, 1998, 47). In Western literary works following Madame Butterfly, Oriental women are just like Butterfly, always obedient, passive, and waiting to be saved and liberated. Being always sacrificial to their Western lovers, self-destruction is usually their inescapable destiny. But the stereotype that underlies the relationship between the West and the East and between men and women is far from correct because it intentionally distorts the relationship to assert the superiority of the West and the masculinity of the Western men. The stereotype is doomed to cause misunderstandings as is shown in the play M. Butterfly.

\section{M. Butterfly: An Intentional Subversion of the Butterfly Stereotype}

David Henry Hwang's M. Butterfly is not only a reinterpretation, but also a subversion of the Western stereotypes of Asia and the Asian people. He has stated that part of the appeal in working on the play lies in his "idea of doing a deconstructivist Madame Butterfly" (Hwang, 1988, 95). In the play, he skillfully incorporates the Butterfly stereotype propagated by Puccini into the love story of the French diplomat, Rene Gallimard, and Song Liling, the Chinese opera singer. The French diplomat is attracted by the opera singer's performance of Madame Butterfly as the "convincing" performance fits more into the stereotype of the Oriental woman in the diplomat's eyes. He is so charmed by the Oriental "woman" or to be more exact, by the image created by Song Liling on purpose, that he is willing to do everything for the Chinese singer, including offering intelligence that her espionage for the Chinese government needs. When Gallimard is imprisoned for information leakage and Song's identity as a man and his mission are made known to him, Gallimard, indulging in his fantasy about the Oriental woman, dresses himself as Madame Butterfly, and commits suicide.

Hwang's play is formulated in contrast with the conventions set up by the opera, Madame Butterfly: the title M. Butterfly alludes to the opera; the narrative of the play also resembles that of the opera in that both of the two deal with the image of the pitiful, submissive Butterfly and the betrayal of the Butterfly's cruel lover. In Western eyes, Oriental women are different from Caucasian women, just like Gallimard says, "Not like American girls. It is true what they say about Oriental girls. They want to be treated bad" (Hwang, 1988, 6). They think it is the Oriental woman's destiny to surrender to and receive cruel treatment from the Caucasian man. Considering the fact that the belief in the Oriental stereotype of an ideal woman can help affirm Western men's masculinity, the seemingly blindness of the Frenchman and the "impossible" story become plausible. Because of the Oriental stereotype, the Westerners know little about real Asia and Asians and "it seemed inevitable that a mistake of this magnitude would one day take place" (Hwang, 1988, 98).

The gender relationship in M. Butterfly is much more complicated than Madame Butterfly. The play's title, M. Butterfly, shows its mimicry to Puccini's opera and reminds the audience of the Oriental stereotype. At the same time, it deliberately blurs the gender reference as M. may stand for Madame, Monsieur, Mr., and Mrs.. Besides, whom $\mathrm{M}$ refers to is also of profound importance. Song, the man masquerading woman, is falsely believed by Gallimard to be his Butterfly, the docile one who is supposed receives cruel treatment from the White lover. Gallimard, who calls himself the Butterfly at the end of the play, is actually the one who is treated cruelly by his lover. In Puccini's story, the tragic heroine is the ideal Asian woman who dies for the love of a Western man. But in M. Butterfly, the tragic character is a Frenchman who commits suicide for love of a Chinese man/woman. In the light of this, the title, M. Butterfly, does not necessarily refer to Song Liling dressed as a woman. It also indicates the gender reversal that Gallimard is going through in the course of the play. In the play, Butterfly, which is used to refer to the ideal Asian woman, can also refer to Gallimard, a man in every sense. In addition to this, the ambiguity in the first name of Gallimard, Rene, further blurs his gender identification. Rene is pronounced the same in both its masculine and feminine forms. The success of Song's masquerade in the play is largely attributable to the overwhelming power of the stereotype and the Westerner's attitude toward the Asians. Brainwashed into believing in the Butterfly myth, Gallimard can be cheated easily by Song, or to be more specific, by his own cultural and gender delusions. As he says,

There is a vision of the Orient that I have. Of slender women in Chong sams and kimonos who die for the love of unworthy foreign devils. Who are born and raised to be the perfect women. Who take whatever punishment we give them, and bounce back, strengthened by love, unconditionally. It is a vision that has become my life. (Hwang, 1988, 91)

When he is attracted to Song Liling's performance of the death scene of Madame Butterfly which arouses Gallimard's stereotype of the Oriental woman and the White man, Gallimard praises Song's performance and 
laments the tragedy of Butterfly, "I've always seen it played by huge women in so much bad makeup...it's the first time I've seen the beauty of the story...it's a very beautiful story." (Hwang, 1988, 17) Song knows Gallimard's Western mentality and responds to Gallimard in a sarcastic tone,

Well, yes, to a Westerner...It's one of your favorite fantasies, isn't it? The submissive Oriental woman and the cruel white man...Consider it this way: what would you say if a blonde homecoming queen fell in love with a short Japanese businessman?...I believe you would consider this girl to be deranged idiot, correct? But because it's an Oriental who kills herself for a Westerner-ah!-you find it beautiful. (Hwang, 1988, 17)

Song's ironic response has made Gallimard speechless and set the tone for the play and foretold that the play will be characterized by ironic reversals that will shatter the well-beloved stereotype completely. Song's questioning Gallimard also shows to us the power relation between Song and Gallimard, the East and the West. After taking initial hold of Gallimard, Song continues her acting and gives the invitation, "If you wish to see some real theatre come to the Peking Opera sometime. Expand your mind" (Hwang, 1988, 17), leaving Gallimard daydreaming of further controlling her and protecting her.

Gallimard begins to imagine the Oriental "woman" to be Madame Butterfly and fancies himself to be Pinkerton. Fitting himself in Pinkerton's role, he wants what Pinkerton had, saying "while we men may all want to kick Pinkerton, very few of us would pass up the opportunity to be Pinkerton" (Hwang, 1988, 42). By identifying with Pinkerton and doing what Pinkerton did, Gallimard is intending to regain his tarnished dignity and his manhood threatened or even damaged in his life in the West since he is unable to find too much sense of male power in his unsatisfactory sexual relationships with his wife and his several Western lovers. Like other Occidentals, his vision of the Orient is also blinded by his sense of superiority of the West and the Oriental myth of docile Asian woman who admires the White man to such an extent that, in spite of his unsatisfactory sexual encounters in the West, he says, "We, who are not handsome, nor brave, nor powerful, yet somehow believe, like Pinkerton, that we deserve a Butterfly" (Hwang, 1988, 10). Gallimard firmly believes in his racial superiority and the stereotype of Oriental women as tender, shy, and conservative in sex and having admiration and awe for Occidental men. His supremacy is reinforced by his White colleague, "She cannot love you, it is taboo, but something deep inside her heart...she cannot help herself...she must surrender to you. It is her destiny...they fear us, Rene. Their women fear us. And their en - their men hate us. And, you know something? They are all correct". (Hwang, 1988, 22) He is opinionated that Song is his Butterfly who is always there waiting for him to conquer at the very beginning. Song's pretended shyness and conservative manners make him feel "for the first time that rush of power - the absolute power of a man" (Hwang, 1988, 32).

When Song appears aggressive, independent, and proud by doing most of the talking and cuts their meeting shorter than Gallimard has expected and asks him to come again in their second meeting, Gallimard is confused, and yet at the same time, as a Westerner and man, he disbelieves things between Song and him, "What was that?...women do not flirt with me. And I normally can't talk to them. But tonight, I held up my end of the conversation." (Hwang, 1988, 20) When Song phones him to give an invitation to The Drunken Beauty, Gallimard feels more positive about his concept about Oriental women, who are conservative and submissive to Western men. This mentality, coupled with Song's maneuvering tricks, makes him falsely believe that Song is his Butterfly and his little Oriental treasure and that their relationship is a typical one between an Occidental man and an Oriental woman with Song being the docile Butterfly totally submitted to her White lover. He gains the sense of domination and power over this Oriental woman.

On the part of Song Liling, who knows very well Gallimard's racial mentality and who, also as a man, knows how a man wants to see in a woman, she creates a fantasy of perfect woman by acting out a woman that is appropriate, in Gallimard's eyes, for her class, race, and nationality and further corners Gallimard in her careful trap. Song criticizes the Westerners' mentality about the East, saying, "the West thinks of itself as masculine - big guns, big industry, big money — so the East is feminine — weak, delicate, poor...but good at art, and full of inscrutable wisdom - the feminine mystique... The West believes the East, deep down, wants to be dominated - because a woman can't think for herself'. (Hwang, 1988, 83) In spite of this, Song is intentionally catering to Gallimard. Modeling on the Butterfly pattern, Song "surrenders" to Gallimard to capture his heart in her letters, "Sometimes I hate you, sometimes I hate myself, but always I miss you...I don't deserve this cruelty...I can hid behind dignity no longer, What do you want? I have already given you my shame" (Hwang, 1988, 30). This has successfully deceived Gallimard into believing that he is a real "Pinkerton" and has had his Butterfly. When Gallimard, like Pinkerton, starts an affair with Renee, Song continues her acting like Butterfly, which makes Gallimard continue fantasizing her as the docile Butterfly, "she would cry, alone in those widely soft sleeves, once full of possessions, now empty to collect her tears. It was her tears and silence that excited me, every time I visited Renee". (Hwang, 1988, 46) Song's pretended pregnancy and the baby reinforce Gallimard's 
fantasy of his male power since he has never impregnated any woman in the West. With all these tricks, Song successfully captures Gallimard's heart. Just like Gallimard says, "All he wants is for her to submit. Once a woman submits, a man is always ready to become generous" (Hwang, 1988, 57), Song begins to make use of the White man's generosity with requirements, "Tell me-what's happening in Vietnam...I want to know what you know. To be impressed by my man." (Hwang, 1988, 33) In this context, Song is the one who has the upper hand. What Song needs to do is to pretend to be subordinate and obedient to satisfy Gallimard's Western arrogance so that she can get whatever she wants from him. Even after many years' separation, he still loves this fantasized woman. When Song's real identity is shown to him, Gallimard still clings to his fantasy of an ideal woman. Dressed in Butterfly, the White man kills himself like Butterfly does for her White lover. It is Gallimard, the White man, who actually surrenders to the Oriental "woman".

But the truth is that Song, the spy, is taking advantage of the Whites' delusions of the Oriental woman to manipulate Gallimard. The man masquerading Butterfly, supposed to be manipulated by others transforms into the power manipulating others. From the very beginning, the Oriental "woman", Song is given the task of gleaning information from her White lover. In this sense, Song is not simply an Oriental woman but a symbol of power. The White man, Gallimard, becomes an embodiment of lack of power. He is made easily speechless by the Oriental woman. The stereotype makes a fool of him, ignorant of the differences of Asian cultures and peoples, unable to see through the difference between a Chinese opera singer and a fictional Japanese tragic heroine. The power structure between men and women and the East and the West is reversed. The submissive Oriental woman who sacrifices everything for her White lover becomes a man. The White man who is supposed to be a sexual exploiter becomes the sexual prey of an Oriental. Sex that is supposed to be the White man's weapon to dominate the Oriental woman becomes an Oriental man's weapon to maneuver the White man for his less powerful country.

\section{Conclusion}

Both Puccini's Madame Butterfly and Hwang's M. Butterfly deal with cross-racial love, in which one of the lovers treats the other cruelly. In Puccini's version, it is stereotyped that the White man is more powerful and the Eastern woman is docile, submissive to the White man just like the East is colonized by the more powerful Western countries. The Oriental woman is destined to be dominated by the White man and to love him purely and to receive the White man's cruel treatment, which results in the Oriental woman's suicide. But Hwang's $M$. Butterfly subverts the Oriental stereotyping about the East and Easterners perpetuated by Madame Butterfly. The Oriental "woman", Song Liling, who is actually a man, pretends to be a Butterfly-like woman to charm Gallimard, the White man, to fulfill his/her task as a spy. In the relationship, the White man, like Cio-Cio-San portrayed in Madame Butterfly, gradually loses himself while Song Liling never forgets his true identity as a man and his mission as a spy. In this sense, the Oriental "woman" is dominating their relationship and becomes the cruel one. Meanwhile, Gallimard sacrifices everything, his career, his reputation, his family, and his life, for Song, the Butterfly in his mind. At the end of the play, Gallimard says, "the love of a Butterfly can withstand many things - unfaithfulness, loss, even abandonment... And I have found her at last. In a prison on the outskirts of Paris. My name is Rene Gallimard-also known as Madame Butterfly" (Hwang, 1988, 91) Gallimard becomes the docile, self-sacrificial Butterfly while Song Liling regains his male identity.

The play totally subverts the binary oppositions that structure the worlds of the West and the East and the relationship between the man and the woman. A different dimension is added to the relationships between the Occidental man and the Oriental woman and between the Occident and the Orient and to the power structure of the West and the East. The Butterfly myth is shattered in Gallimard's mind as it has completely blinded him, just like Hwang wrote,

I'd like to think Butterfly says to an audience, "All right, we'll give you the orientalia you seem to desire, but then we're going to talk about why you're so attracted to this, and how that attachment to stereotype blinds you to the truth of your own experience"-in the case of my play's deceived Frenchman, even to the extent of being unable to tell the true gender of his lover. (Hwang, 1989, 18).

Thus, the play reveals to us the insidiousness of stereotyping, which is attacked as biggest barrier in the play for Gallimard to understand Asians and Asian culture. The stereotype about the Orientals prevents people of different cultures and nations from truthful contacts as people are too saturated in the stereotype. Therefore, ridding ourselves of cultural misconceptions and racial stereotypes is prerequisite for a better understanding of other cultures and other peoples when we are in cross-cultural communications. 


\section{References}

Carigani, Carlo. (1976). Madame Butterfly: A Japanese Tragedy. New York: G. Riocordi \& Co., Fred Rullman, Inc..

Hwang, David Henry. (1988). M. Butterfly. New York: Penguin.

Hwang, David Henry. (1989). Evolving a Multicultural Tradition. MELUS, 16(3), 16-19. http://dx.doi.org/10.2307/467559

Kerr, Douglas. (1991). David Henry Hwang and the Revenge of Madame Butterfly. In Chan Mimi, \& Harris Roy (Eds), Asian Voices in English (pp. 119-130). Hong Kong: Hong Kong University Press.

Kondo, Dorrinek. (Fall, 1990). M. Butterfly: Orientalism, Gender and a Critique of Essentialist Identity. Culture Critique, 5-29. http://dx.doi.org/10.2307/1354343

Ling, Amy. (1990). Between Worlds: Women Writers of Chinese Ancestry. New York: Pergammon Press.

Lomba. (1998 A). Colonialism/Postcolonialism. London: Routledge and Kegan Paul Ltd.

Loti, Pierre. (1985). Madame Chrysanthemum (trans. Laura Ensor). London: KPI.

Said, Edward W. (1978). Orientalism. London: Routledge \& Kegan Paul Ltd. 